\title{
Can NLR be Used in Discriminating Simple and Severe Cholecystitis in Emergency Department Admission?
}

\author{
Acil Servis Başvurularında Basit ve Şiddetli Kolesistit Ayırımında NLO \\ Kullanılabilir mi?
}

\author{
Hasan Basri Çetinkaya ${ }^{1}$, Ferhat Çay ${ }^{2}$ \\ ${ }^{1}$ Ballkesir University Department of Emergency Medicine, Bahkesir/Turkey \\ ${ }^{2}$ Ballkesir University School of Medicine Department of General Surgery Ballkesir/Turkey
}

\begin{abstract}
Objective: Acute cholecystitis is a common surgical emergency case, and the progress of simple cholecystitis to severe cholecystitis results in preoperative inflammatory and metabolic complications and a longer hospital stay. We aimed to determine whether the neutrophil-lymphocyte ratio (NLR) could help discriminate between simple and severe cholecystitis in emergency department admissions.

Materials and Methods: All patients who were aged 18 or older, were diagnosed with acute cholecystitis, and presented to emergency department were included in our retrospective study. Blood laboratory values of patients who were diagnosed with acute cholecystitis in emergency department and whose preoperative diagnosis was confirmed were taken. Patients with secondary changes associated with acute cholecystitis, such as gangrenous cholecystitis and gallbladder perforation, were included in the severe cholecystitis group.

Results: The study consisted of 54 patients, including 45 $(83.33 \%)$ with simple cholecystitis and $9(16.67 \%)$ with severe cholecystitis. Of the 54 patients, 28 (51.85\%) were male, 26 $(48.15 \%)$ were female, and the median age was 71 years (minimum-maximum: 27-94). NLR was found significantly higher in the severe cholecystitis group compared to the simple cholecystitis group. Besides, there was a significant difference between the two groups in terms of CRP, WBC, neutrophil, and lymphocyte values.

Conclusion: Early discrimination of simple and severe cholecystitis in patients presenting to the emergency department with right upper quadrant pain is important in terms of patient management. We think it may be useful to utilize the NLR to discriminate between simple and severe cholecystitis.

Key Words: Simple cholecystitis; severe cholecystitis; neutrophil-lymphocyte ratio
\end{abstract}

\section{Introduction}

Abdominal pain is a common complaint among emergency department (ED) admissions. Acute cholecystitis, which is among the causes of abdominal pain, is one of the leading gastrointestinal diseases that require hospitalization and surgical treatment. Acute cholecystitis is a disease that results in swelling

\begin{abstract}
Özet
Amaç: Akut kolesistit acil cerrahi gerektiren durumların yaygın nedenlerinden biridir ve basit kolesistitin şiddetli kolesistite ilerlemesi, ameliyat öncesi inflamatuar ve metabolik komplikasyonlara ve hastanede kalıs süresinin uzamasına neden olur. Acil servis başvurularında nötrofil-lenfosit oranının (NLO) basit ve şiddetli kolesistiti ayırt etmeye yardımcı olup olamayacă̆ını belirlemeyi amaçladık.

Gereç ve Yöntemler: Retrospektif çalıșmamıza acil servisimize karın ağrısı şikayeti ile başvuran 18 yaş ve üzeri akut kolesistit tanısı alan tüm hastalar dahil edildi. Akut kolesistit tanısı alan ve ameliyat öncesi tanısı doğrulanan hastaların kan laboratuvar değerleri alındı. Gangrenöz kolesistit ve safra kesesi perforasyonu gibi akut kolesistit ile ilişkili sekonder değişiklikleri olan hastalar şiddetli kolesistit grubuna dahil edildi.
\end{abstract}

Bulgular: Çalışma 45'i (\%83.33) basit kolesistit ve 9'u (\%16.67) şiddetli kolesistit olmak üzere 54 hastadan oluştu. 54 hastanın 28'i (\%51.85) erkek, 26's1 (\%48.15) kadın ve ortanca yaş 71 (minimum-maksimum:27-94) idi. NLO, şiddetli kolesistit grubunda basit kolesistit grubuna göre anlamlı olarak yüksek bulundu. Ayrıca CRP, WBC, nötrofil ve lenfosit değerleri açısından iki grup arasında anlamlı fark vardı.

Sonuç: Sağ üst kadran ağrısı ile acil servise başvuran hastalarda basit ve şiddetli kolesistitin erken dönemde ayırt edilmesi hasta yönetimi açısından önemlidir. Basit ve şiddetli kolesistiti ayırt etmek için NLO oranını kullanmanın yararlı olabileceğini düşünüyoruz.

Anahtar Kelimeler: Basit kolesistit; şiddetli kolesistit; nötrofillenfosit oran1

and inflammation of the gallbladder (1). The clinical symptoms include vomiting, fever, and especially right upper quadrant pain. Delay in surgical treatment may cause simple cholecystitis to progress to severe cholecystitis (gangrenous cholecystitis and/or gallbladder perforation). Some laboratory parameters, such as positive Murphy's sign, high levels of leukocyte, and C- 
reactive protein (CRP), are guiding in the diagnosis in the ED; yet, they are not decisive findings for diagnosis on their own (2). Neutrophil lymphocyte ratio (NLR) is a parameter that is easily calculated by the proportion of neutrophil to lymphocyte counts determined by complete blood count. Its effectiveness has frequently been evaluated in various diseases recently. Some publications have shown that it can be used in the diagnosis of many diseases (coronary artery diseases, malignancies, diabetes mellitus, appendicitis, etc.), as well as determining the severity of some diseases (3-6). Of the causes of abdominal pain related to NLR, there are many publications related to acute appendicitis in the literature, and some of which also argue that it is particularly effective in determining the severity of appendicitis (7-9). In the current study, we aimed to determine the role of NLR in discriminating between simple and severe cholecystitis in patients with cholecystitis frequently presenting to ED.

\section{Materials and Method}

Patients who presented to our ED with abdominal pain and diagnosed with acute cholecystitis between February 01, 2019 and November 01, 2020 were examined. Inclusion criteria were physical examination findings such as right upper quadrant pain and laboratory parameters, such as positive inflammation parameters and simple or severe(gangrene and perforation) cholecystitis on abdominal USG and/or abdominal tomography. Exclusion criteria were negative simple or severe cholecystitis parameters on abdominal USG and/or abdominal tomography despite anamnesis and clinical physical examination findings compatible with acute cholecystitis. This study was conducted in accordance with the Declaration of Helsinki, which regulates biomedical studies with humans. Ethics committee approval of the study was obtained from our instution with decision number 2020/181.

Statistical analysis: Shapiro-Wilk test was used to test the normality of the variables. Continuous variables were presented as median (minimummaximum) values since the data were not normally distributed. Mann-Whitney's U-test was employed to compare two independent groups. Categorical variables were expressed by counts and percentages. Comparisons between the groups were made with Fisher's exact chi-square test for categorical variables. Risk factors were evaluated with binary logistic regression analysis. Receiver operating characteristics (ROC) curve analysis was performed to evaluate and compare the performances of diagnostic markers. The significance level was taken as $\alpha=0.05$. Statistical analyses were performed with IBM SPSS Statistics version 22.0 (IBM Corp., USA) and MedCalc version 12.3.0.0.

\section{Results}

The study included 54 patients, $45(83.33 \%)$ of whom had simple cholecystitis, and 9 (16.67\%) of whom had severe cholecystitis. Of the 54 patients, $28(51.85 \%)$ were male and $26(48.15 \%)$ were female. The median age was 71 (minimummaximum: 27-94) years. There was a significant difference between simple cholecystitis and severe cholecystitis patient groups in terms of NLR. NLR was significantly higher in the severe cholecystitis group than the simple cholecystitis group $(\mathrm{p}<0.001)$. Also, there was a significant difference between the two groups in terms of CRP, WBC, neutrophil and lymphocyte values (Table 1). We conducted a backward conditional logistic regression analysis by including the variables which were found statistically significant in univariate analysis in the model, except neutrophil and lymphocyte, since they create the NLR variable. The model was statistically significant $(\mathrm{p}<0.001$ for the Omnibus test; $\mathrm{p}=0.787$ for the Hosmer-Lemeshow test). One unit increase in the NLR increased the risk of severe cholecystitis 1.159 times $(p=0.042)$, and one unit increase in the CRP increased the risk of severe cholecystitis 1.031 times $(\mathrm{p}=0.042)$ times compared to the simple cholecystitis group (Table 2). While in the simple cholecystitis group, only USG was planned for $n=23(51.11 \%)$ patients and USG+BT was planned for $\mathrm{n}=22(48.89 \%)$ patients, in the severe cholecystitis group, USG+BT was planned for all of the patients $(n=9,100 \%) \quad(p=0.007)$. We performed ROC curve analyses to evaluate the diagnostic performances of pulse rate, neutrophil, lymphocyte, CRP and NLR in discriminating between simple and severe cholecystitis patients. Significant diagnostic performances were obtained for CRP $(p<0.001)$. The performance of NLR in discriminating between simple cholecystitis and severe cholecystitis patients was statistically significant $(A U C=0.896, p<0.001)$. AUC values for CRP, neutrophil, lymphocyte, were also statistically significant. Optimal cut-off values were obtained according to the Youden $\mathrm{J}$ index, and corresponding sensitivity and specificity values were given. No significant difference was found between the diagnostic performance of the NLR and CRP in discriminating between simple 
Table 1: Comparison of patient characteristics between simple and severe cholecystitis patients

\begin{tabular}{llll}
\hline Variable & $\begin{array}{l}\text { Simple cholecystitis } \\
\text { n (min-max) }\end{array}$ & $\begin{array}{l}\text { Severe cholecystitis } \\
\text { n (min-max) }\end{array}$ & p-value \\
\hline Age $($ year) & $70(27-90)$ & $78(37-94)$ & 0.072 \\
NLR & $5.96(1.70-30.60)$ & $20.71(10.07-43.60)$ & $<0.001$ \\
CRP $(\mathrm{mg} / \mathrm{dL})$ & $45(3-199)$ & $188(12-207)$ & 0.002 \\
Neutrophil $\left(\times 10^{3} / \mathrm{L}\right)$ & $9.05(3.30-21.10)$ & $15.50(6.00-38.40)$ & 0.010 \\
Lymphocyte $\left(\times 10^{3} / \mathrm{L}\right)$ & $1.40(0.50-3.50)$ & $0.90(0.30-1.50)$ & 0.011 \\
\hline
\end{tabular}

Data given as median (minimum-maximum) or $\mathrm{n}(\%)$

Table 2: Results of logistic regression analysis

\begin{tabular}{|c|c|c|c|c|}
\hline \multirow{2}{*}{$\begin{array}{l}\text { Independent } \\
\text { variables }\end{array}$} & \multirow{2}{*}{$\mathrm{p}$-value } & \multirow{2}{*}{ OR } & \multicolumn{2}{|c|}{$95 \%$ CI for OR } \\
\hline & & & Lower & Upper \\
\hline NLR & 0.042 & 1.159 & 1.006 & 1.335 \\
\hline CRP & 0.042 & 1.031 & 1.001 & 1.062 \\
\hline
\end{tabular}

OR: Odds ratio, CI: Confidence interval

Table 3: ROC curve analysis results

\begin{tabular}{|c|c|c|c|c|c|c|}
\hline & AUC & p-value & $\begin{array}{l}\text { cut-off } \\
\text { value }\end{array}$ & $\begin{array}{l}\text { Youden J } \\
\text { index }\end{array}$ & $\begin{array}{l}\text { Sensitivity } \\
(95 \% \mathrm{CI})\end{array}$ & $\begin{array}{l}\text { Specificity } \\
(95 \% \text { CI })\end{array}$ \\
\hline NLR & 0.896 & $<0.001$ & $>9.63$ & 0.727 & $\begin{array}{l}100.00 \\
(66.4-100.0)\end{array}$ & $\begin{array}{l}72.73 \\
(57.2-85.0)\end{array}$ \\
\hline CRP & 0.820 & $<0.001$ & $>166$ & 0.607 & $\begin{array}{l}77.78 \\
(40.0-97.2)\end{array}$ & $\begin{array}{l}82.93 \\
(67.9-92.8)\end{array}$ \\
\hline Neutrophil & 0.770 & 0.003 & $>14.4$ & 0.573 & $\begin{array}{l}77.78 \\
(40.0-97.2)\end{array}$ & $\begin{array}{l}79.55 \\
(64.7-90.2)\end{array}$ \\
\hline Lymphocyte & 0.768 & $<0.001$ & $\leq 1.5$ & 0.455 & $\begin{array}{l}100.00 \\
(66.4-100.0)\end{array}$ & $\begin{array}{l}45.45 \\
(30.4-61.2)\end{array}$ \\
\hline
\end{tabular}

CI: Confidence interval

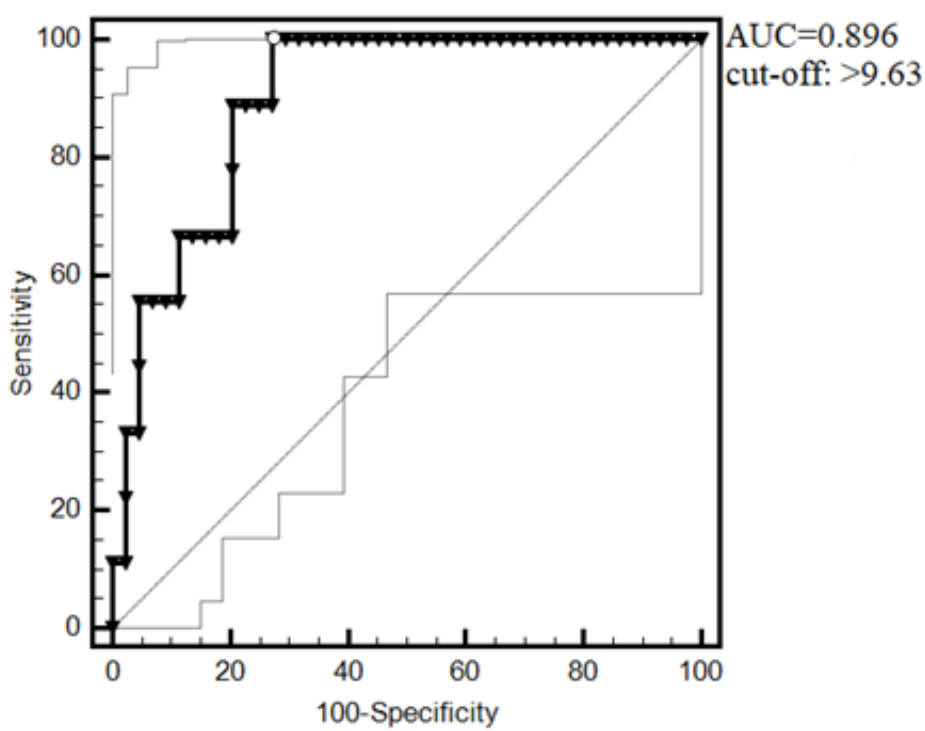

Figure 1. ROC curve for NLR

AUC: Area under the curve

Van Tip Derg Cilt:28, Sayı:4, Ekim/2021 
and severe cholecystitis patients $(\mathrm{p}=0.416)$ (Table 3, Figure 1).

\section{Discussion}

Severe cholecystitis causes more tissue damage and complications than simple cholecystitis. Early detection of severe cholecystitis is important to prevent perioperative inflammatory and metabolic complications and a longer hospital stay (10). A complete blood count is an easy, fast and inexpensive test. Values, such as white blood cell count and neutrophil, lymphocyte and platelet count in this test, can be used as inflammatory markers (11). The ratios of some values in this test, particularly NLR and CRP, have been studied as inflammatory markers in some studies $(11,12)$. Liu et al. (13) found that as the severity of sepsis increased, the NLR increased, as well. They examined 333 patients with sepsis admitted to the intensive care unit and found that the NLR values of patients who died of sepsis were significantly higher than those who survived. In our study, too, the increase in the NLR value was found to be associated with the severity of inflammation and the severity of the disease in acute cholecystitis. In another study, NLR was shown to help diagnose acute appendicitis in patients with right lower quadrant pain. While the cut-off value for NLR was 4.68 in patients with suspected appendicitis, this rate was observed to increase to 5.74 in perforated appendicitis (14). In our study, while the mean NLR value was 5.96 in patients with simple cholecystitis, it increased to 20.71 in severe cholecystitis cases including perforated cholecystitis. In our study, we found the cut-off value for severe cholecystitis as 9.63. This finding indicated that the NLR values increased statistically with the increase in the intensity of gallbladder inflammation in parallel with the NLR value increasing with the severity of inflammation in appendicitis. Lee et al. (15) found that the NLR value that is greater than 3 was associated with death and severity. In our study, the NLR value was greater than 9.63 for acute cholecystitis cases, and this was associated with severe cholecystitis. Ertok et al. (16) found that NLR increased in parallel with the increase in inflammation in patients with cholecystitis. They found the cut-off value for NLR as 4.115 with a sensitivity of $75.9 \%$ and a specificity of $77.7 \%$. In our study, the cutoff value for discriminating between simple and severe cholecystitis was found as 9.63 with a sensitivity of $100.00 \%$ and a specificity of $72.73 \%$. Beliaev et al. (17) and Asai et al. (18) stated that NLR values greater than 4.17 might be significant for determining cholecystitis. In our study, we found that the NLR value was significant for discriminating between simple and severe cholecystitis and that the cut-off value was 9.63. In the same studies, they found that CRP values increased markedly and suggested that it could be used as an indicator of the severity of cholecystitis $(17,18)$. In our study, the CRP value had significantly increased in severe cholecystitis cases compared to simple cholecystitis, and a CRP value of greater than 166 was significant for severe cholecystitis. In a study conducted by Başol et al. (19) the sensitivity and specificity values were $70 \%$ and $73.2 \%$, respectively, for a CRP cut-off value of 9.5 in cholecystitis cases. In our study, on the other hand, the sensitivity and specificity values for the CRP cut-off value of 166 for discriminating between simple and severe cholecystitis cases were $77.78 \%$ and $82.93 \%$, respectively.

\section{Conclusion}

We argue that discriminating between simple and severe cholecystitis cases is important in the management and early diagnosis of acute cholecystitis cases, which are very common in ED, and that it may be beneficial to utilize NLR values in discriminating between the two.

Ethics committee approval: The study was approved by Ethics Committee of Balikesir University Faculty of Medicine and was conducted in accordance with the principles of the Declaration of Helsinki (decision no: 2020/181).

Informed consent: An informed consent form was obtained from each patient.

Peer-review: Externally peer-reviewed.

\section{Authorship contributions}

Concept: H.B.Ç, Design: F.Ç, Data Collection or Processing: H.B.Ç, F.Ç, Analysis or Interpretation: H.B.Ç, Literature Search: H.B.Ç, Writing: H.B.Ç, F.C..

Conflict of interest: The authors declared no potential conflicts of interest with respect to the research, authorship, and/or publication of this article.

Financial disclosure: The authors received no financial support for the research, authorship, and/or publication of this article.

\section{References}

1. Fialkowski E, Halpin V, Whinney RR. Acute cholecystitis. BMJ Clin Evid 2008;2008:0411.

2. Hwang H, Marsh I, Doyle J. Does ultrasonography accurately diagnose acute cholecystitis? Improving diagnostic 
accuracy based on a review at a regional hospital. Can J Surg 2014;57(3):162-168.

3. Prajapati JH, Sahoo S, Nikam T, Shah KH, Maheriya B, Parmar M. Association of high density lipoprotein with platelet to lymphocyte and neutrophil to lymphocyte ratios in coronary artery disease patients. J Lipids 2014;2014:686-791.

4. Yilmaz H, Ucan B, Sayki M, Unsal I, Sahin M, Ozbek $M$ et al. Usefulness of the neutrophil-to-lymphocyte ratio to prediction of type 2 diabetes mellitus in morbid obesity. Diabetes \& metabolic syndrome 2015;9(4):299-304.

5. Chen $\mathrm{ZY}$, Raghav $\mathrm{K}$, Lieu $\mathrm{CH}$, Jiang $\mathrm{ZQ}$, Eng C, Vauthey JN et al. Cytokine profile and prognostic significance of high neutrophil-lymphocyte ratio in colorectal cancer. Br J Cancer 2015;112(6):1088-97.

6. Chen Q, Yang LX, Li XD, Yin D, Shi SM, Chen EB et al. The elevated preoperative neutrophil-to-lymphocyte ratio predicts poor prognosis in intrahepatic cholangiocarcinoma patients undergoing hepatectomy. Tumour Biol. 2015;36(7):5283-5289.

7. Shimizu T, Ishizuka M, Kubota K. A lower neutrophil to lymphocyte ratio is closely associated with catarrhal appendicitis versus severe appendicitis. Surg Today 2016;46(1):84-89.

8. Narc1 A, Tuncer AA, Çetinkurşun S. Çocukluk çağ1 apendisitlerinde nötrofil/lenfosit oranının tanısal değeri. Kocatepe Tip Dergisi 2009;10:5-7.

9. Kahramanca S, Ozgehan G, Seker D, Gökce EI, Seker G, Tunç $G$ et al. Neutrophil-to-lymphocyte ratio as a predictor of acute appendicitis. Ulus Travma Acil Cerrahi Derg 2014;20(1):1922.

10. Yuksel M, Ates I, Kaplan M, Arikan MF, Ozin YO, Kilic ZMY et al. Is Oxidative Stress Associated with Activation and Pathogenesis of Inflammatory Bowel Disease? J Med Biochem 2017;36(4):341348.

11. Balta S, Demirkol S, Unlu M, Arslan Z, Celik T. Neutrophil to lymphocyte ratio may be predict of mortality in all conditions. $\mathrm{Br} \quad \mathrm{J} \quad$ Cancer 2013;109(12):3125-3126.

12. Nazik H, Nazik S, Çoban F. nötrofil lenfosit ve platelet lenfosit oranlarının aktif behçet hastalarındaki önemi. Bozok Tip Dergisi 2016;6(3):33-36

13. Liu X, Shen Y, Wang H, Ge Q, Fei A, Pan S. Prognostic Significance of Neutrophilto-Lymphocyte Ratio in Patients with Sepsis: A Prospective Observational Study. Mediators Inflamm 2016;2016:8191254.

14. Kahramanca S, Ozgehan G, Seker D, Gökce EI, Seker G, Tunç $G$ et al. Neutrophil-to-lymphocyte ratio as a predictor of acute appendicitis. Ulus Travma Acil Cerrahi Derg 2014;20(1):1922.

15. Lee SK, Lee SC, Park JW, Kim SJ. The utility of the preoperative neutrophil-tolymphocyte ratio in predicting severe cholecystitis: a retrospective cohort study. BMC Surg. 2014;14:100.

16. Ertok I, Karakayalı O, Kocasaban DU. Clinical Importance Of Neutrophil/Lymphocyte Ratio In Differential Diagnosis Of Acute Cholecystitis And Cholelithiasis. Kocaeli Med J 2016;5(3):6-11

17. Beliaev AM, Marshall RJ, Booth M. Creactive protein has a better discriminative power than white cell count in the diagnosis of acute cholecystitis. J Surg Res 2015;198(1):66-72.

18. Asai K, Watanabe M, Kusachi S, Matsukiyo H, Saito T, Kodama $\mathrm{H}$ et al. Risk factors for conversion of laparoscopic cholecystectomy to open surgery associated with the severity characteristics according to the Tokyo guidelines. Surg Today 2014;44(12):23002304.

19. Başol N, Çı̆şar G, Karaman S, Özsoy Z, Özdemir MB. The evaluation of patients with acute cholecystitis in the Emergency Department according to neutrophil lymphocyte ratio and epidemiological factors: three years analysis. İstanbul Bilim University Florence Nightingale Med J 2015;1:145-149. 